\title{
Д. Лувсаншарав - бывший монах и партийный деятель
}

\section{Кеемя Владимировна Орлова}

${ }^{1}$ Институт востоковедения РАН (д. 12, ул. Рождественка, 107031 Москва, Российская Федерация) доктор исторических наук, кандидат филологических наук, ведущий научный сотрудник

iD 0000-0003-4951-0063. E-mail: orlovnk@mail.ru

(C) КалмНЦ РАН, 2020

(C) Орлова К. В., 2020

Аннотация. Введение. В XX в. в Монголии выдвинулась плеяда партийных и государственных деятелей, жизнь и карьера которых сложилась по-разному. Среди них обращает на себя внимание группа партийных функционеров, которые пришли в политику с хорошим образованием из буддийских монастырей, со знанием языков. В этом ряду выделяется буддийский священнослужитель Д. Лувсаншарав (1900-1941 гг.) с 20-летним стажем пребывания в Мурэнском монастыре. Неизвестно, какое образование и специализацию получил (и получил ли?) в одном из крупных монастырей Монголии, но, по свидетельству его партийных соратников и его собственному признанию, считался специалистом по ламскому вопросу. После учебы в Москве в Коммунистическом университете трудящихся Востока (1928-1929 гг.) началось его постепенное восхождение на партийный олимп. Вершиной деятельности Лувсаншарава стала работа в ламской комиссии, главной целью которой была обозначена ликвидация реакционного ламства (а по сути буддийских священнослужителей как сословия), и участие в составе особой полномочной комиссии (так называемой «тройки»), результатом деятельности которой стали невосполнимые потери сотни и тысяч людей, частичная утрата материальных ценностей и традиционной культуры. Цель статьи - раскрыть по возможности роль бывшего ламы на партийном поприще, понять мотивы такой трансформации. Материалы. В статье использованы материалы из Центрального архива ФСБ России, сборника «Монголия в документах Коминтерна» (ч. I, II). Результаты. После национально-демократической революции 1921 г. в Монголии остро встал вопрос кадров, начались поиски «пригодных к административной, хозяйственной и военной работе» не только из среды простых аратов, но и ламства и монгольской знати, которые привели к руководству страной людей с разными способностями и восприятием мира. Среди такой публики выдвинулся Д. Лувсаншарав. Судя по архивным документам, Д. Лувсаншарав являлся личностью очень неоднозначной и противоречивой. Сподвижники по партии, сотрудники секретариата Восточного Исполнительного комитета Коммунистического интернационала, однозначно характеризовали его как честолюбивого, не отличающегося твердостью и выдержкой, недостаточно деловитого, нерешительного, человеком 


\section{История}

«второго плана». Тем не менее, бывший буддийский священнослужитель стал одним из партийных руководителей. Причины столь разительной перемены в жизни и карьере Д. Лувсаншарава, видимо, кроются в его характере, нереализованности на поприще религии, возможно, неудовлетворенности занимаемым местом в структуре крупного монгольского монастыря. Вполне вероятно, что толчком к уходу из монастыря послужили какие-то психологические моменты. Нельзя исключать и резкую смену идеологии, соответственно, и мировоззрения (когда во главу угла часть людей ставила личную выгоду и карьеризм) в этот непростой, даже жесткий период в истории страны. Ключевые слова: Лувсаншарав, Монголия, лама, Монгольская народно-революционная партия, буддизм

Благодарность. Автор выражает глубокую благодарность коллегам - Ph.D., врио директора Института истории и этнологии АН Монголии Норовсамбуу Хишигт, доктору исторических наук В. В. Грайворонскому, доктору исторических наук С. Л. Кузьмину - за ценные советы, предложения, критические замечания, высказанные в ходе подготовки статьи.

Для цитирования: Орлова К. В. Д. Лувсаншарав - бывший монах и партийный деятель // Монголоведение. 2020. Т. 12. № 3. С. 370-383. DOI: 10.22162/2500-1523-2020-3-370-383

UDC 94(517)

DOI: $10.22162 / 2500-1523-2020-3-370-383$

\section{Luvsansharav — Ex-Monk and Party Activist}

\section{Keemya V. Orlova ${ }^{1}$}

${ }^{1}$ Institute of Oriental Studies of the RAS (12, Rozhdestvenka St., Moscow 107031, Russian Dr. Sc. (History), Cand. Sc. (Philology), Leading Research Associate

iD 0000-0003-4951-0063. E-mail: orlovnk@mail.ru

(C) KalmSC RAS, 2020

(C) Orlova K. V., 2020

Abstract. Introduction. In the $20^{\text {th }}$ century, Mongolia witnessed the emergence of a number of party activists and statesmen whose formally differing life paths and careers largely resulted in essentially similar repressions experienced. Those included a group of party executives with monastic backgrounds and good command of foreign languages. And it is D. Luvsansharav who had spent twenty years in Mörön Monastery that attracts special attention. It is unknown what (and whether at all) he had studied at the monastic college — a largest one in the country - but his party comrades (and himself) considered him to be an expert in the Lamaist question. On graduation from the Communist University of the Toilers of the East (1928-1929), he begins a political career, the pinnacle of which being his work at the Lamaist Commission that primarily aimed to eradicate reactionist Lamaist elements (i.e., the whole of Buddhist clergy as such), and his participation in the Plenipotentiary Commission (a so called 'troika') that put to death hundreds and even thousands of citizens, destroyed some precious items of material and traditional culture. Goals. The paper seeks to reveal the ex-monk's impact in party arrangements, interpret certain personal motives to have underlain the transformation. Materials. The 
work analyzes materials stored at the Central Archive of the Federal Security Service and contained in Mongolia in Documents of the Comintern (vols. 1, 2), other scholarly sources. Results. The Mongolian Revolution of 1921 uncovered the lack of competent personnel which lead to a search of 'individuals suitable for administrative, economic, and military work' not only among commoners but also monks and nobility, resulting in that the recruited executives differed both in skills and worldviews. The context proved favorable enough to D. Luvsansharav who - according to archival notes - was quite an ambiguous and contradictive figure. His party comrades and official secretaries of the Eastern Executive Committee of the Communist International characterized him as a definitely ambitious but short-tempered, awkward, and irresolute person in a supporting role. However, the ex-cleric became a leading party activist, and such a dramatic change in his life and career may have stemmed from religious underachievement, dissatisfaction with the position he had held in the large Mongolian monastery, or some psychological aspects. Still, the harsh and severe period of national history could actually give rise to changes in his ideological views and mentality (when personal benefits and career opportunities were viewed by some as priorities).

Keywords: Luvsansharav, Mongolia, Mongolian People's Revolutionary Party, Buddhism Acknowledgements. Author expresses gratitude to Dr. Norovsambuu Khishigt, acting Director of the Institute of History and Ethnology of Mongolian Academy of Sciences, Dr. Sc. V. V. Graivoronsky, and Dr. Sc. S. L. Kuzmin for valuable advice, suggestions, and censorious remarks made during the preparation of the article.

For citation: Orlova K. V. D. Luvsansharav - Ex-Monk and Party Activist. Mongolian Studies (Elista). 2020. Vol. 12. No. 3. Pp. 370-383. (In Russ.). DOI: 10.22162/2500-15232020-3-370-383

\section{Введение}

После национально-демократической революции в 1921 г. в Монголии выдвинулась целая плеяда новых, молодых государственных и партийных деятелей, у которых по-разному сложилась жизнь и политическая карьера, многие оказались репрессированными, хотя честно служили своей родине. Одна из таких личностей - бывший монах Доргижавын Лувсаншарав (1900-1941 гг.), который сделал головокружительную партийную карьеру.

Лувсаншарав родился в 1900 г. в Хан-Тайшир-ул (ныне Гоби-Алтайском) аймаке Монголии в обычной аратской семье. Как правило, в то время каждая монгольская семья отправляла в монастырь одного или двух своих сыновей. Эта участь выпала нашему герою и его родному брату. По собственному признанию Лувсаншарава, около 20 лет $^{1}$ он провел в Мурэнском монастыре [Монголия в документах 2019: 270, 275]. В 1924 г. он снял с себя монашеские обеты и пошел служить в армию, в 1925-1927 гг. возглавил местную партийную ячейку, затем последовала работа в местном отделении кооператива (Монценкооп) и председателем парткома аймака Хан-Тайшир-ул [Монголия в документах Коминтерна 2012б: 450]. Следующий этап - учеба в Центральной партийной школе в УланБаторе (1927-1928 гг.). Как один из активных членов группы студентов, он поддерживал взгляды «левого» крыла в Монгольской народно-революционной партии (далее - МНРП) и выступал против политики «правых». Обучение в

\footnotetext{
${ }^{1}$ По данным С. К. Рощина, с 10 лет [Рощин 1999: 240; Рощин 2008: 93]. Если принять информацию С. К. Рощина, в монастыре он провел всего 14 лет. Однако, если исходить из собственных слов Лувсаншарава, в монастырь отдали в четыре года.
} 


\section{История}

Коммунистическом университете трудящихся Востока² (далее - КУТВ, период учебы 1928-1929 гг.), видимо, лишь еще более укрепило его левые настроения: «левонастроенная часть студенчества приходит к выводу, что им нужно готовиться к борьбе с ламством, нужно встать на путь более решительной борьбы с ним, не оказывая ему ... той или иной поддержки» [Монголия в документах 2019: 140].

По окончании учебы в Москве Д. Лувсаншарав вернулся в аймак ХанТайшир-ул, где работал заведующим орготделом айкома партии, председателем партийной комиссии (1929-1930 гг.). На VIII съезде (1930 г.) МНРП Д. Лувсаншарав избран членом ЦК партии, на первом пленуме ЦК - членом Президиума, заместителем секретаря ЦК, заведующим организационным отделом ЦК МНРП (с апреля 1930 по июнь 1932 гг.). Следующий виток партийной карьеры Лувсаншарава - заместитель секретаря ЦК МНРП, с июня 1932 по июль 1939 гг. - секретарь ЦК МНРП, делегат VII-IX Великих хуралов, член президиума ЦК партии, председатель ламской комиссии ЦК. В июле 1939 г. арестован, 27 июля 1941 г. расстрелян, в 1962 г. реабилитирован [Монголия в документах 2019: 471; Коминтерн ба Монгол 1996: 485; Монголия в документах Коминтерна 2012б: 450; Рощин 1999: 240, 241].

Основными материалами статьи послужили документы из Центрального архива ФСБ России, сборника «Монголия в документах Коминтерна» (ч. I, II), научной литературы. Цель статьи - раскрыть по возможности роль бывшего ламы на партийном поприще, понять мотивы такой трансформации.

\section{Начало жизненного пути}

Изложенная выше биография Д. Лувсаншарава - обычная, ничем не примечательная биография (от главы сомонной партийной организации аймака до секретаря ЦК партии) партийного функционера, если бы не одно «но» 一 он был буддийским священнослужителем, который прослужил около 20 лет в стенах

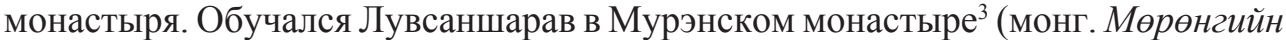

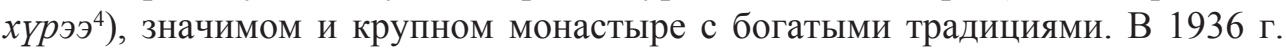
в монастыре насчитывалось свыше 1000 лам-хувараков (по другим данным, свыше 1300 [Монголын сүм хийдийн түүхэн 2009: 724-725; Монголын хүрээ хийд 2018: 321]), со степенью аграмба состояло 25 лам, гавж - 33, маарамба — $14^{5}$, т. е. высокий статус лам подтверждает значимость хурээ. Состав монасты-

\footnotetext{
2 По решению правительства Монголии первая группа молодых монголов была отправлена на учебу в КУТВ в августе 1921 г. Основная цель обучения молодых монголов в КУТВ состояла в том, чтобы «создать из них в будущем молодые кадры революционно настроенных работников» [Монголия в документах 2019: 138].

${ }^{3}$ Основан в 1765 г. в хошуне Ахай бэйсэ Сайнноёнханского (ныне - Хубсугульский) аймак [Монголын сүм хийдийн түүхэн 2009: 725].

${ }^{4}$ Различаются три вида монастырей - хүрээ, сүм и хийд (кид), разные наименования соответствуют «особенностям своей жизни и по складу своего быта» [Позднеев 1993: 1]. В хүрээ ламы жили постоянно, монастыри располагались кругом [Позднеев 1993: 1]. К началу ХХ в. эти наименования уже слабо отражали исходные различия. Ныне, как правило, хүрээ обозначают крупные монастыри.

${ }_{5}^{5}$ Аграмба - степень, присваиваемая окончившим тантрийский факультет; гавж - ученая степень прослушавшего курс философии; маарамба - степень, присваиваемая окончившему медицинский факультет [Сүхбаатар 1997: 115].
} 
ря - Дуйнхор-дацан и Бадам Ёго (время основания 1799 г.), цаннид-дацан (1812 г.), хайлан-хурал (1814 г.), Майдарийн сум (1842 г.), джуд-дацан (1861 г.), манба-дацан (1875 г.), зурхай-дацан (1892 г.) - однозначно свидетельствует о разных его специализациях [Монголын сүм хийдийн түүхэн 2009: 725], кроме того, в хурээ значились 23 дугана, 20 субурганов [Монголын хүрээ хийд 2018: 321]. В джуд-дацане (чойра) изучали пять больших наук (монг. энэтхэгийн их таван ухааныл сурах болов) [Монголын хүрээ хийд 2018: 321]. Судя даже по количеству лам с учеными степенями и специализациями данного монастыря, можно утверждать, что Лувсаншарав мог получить хорошее буддийское образование. К сожалению, какую именно специализацию получил (и получил ли?), неизвестно, а его брат в том же монастыре достиг «разряда высших лам» (либо занимал один из высших постов в монастыре, либо по уровню образования) [Монголия в документах 2019: 277]. Возможно, данные о монастырском прошлом Лувсаншарава можно выявить в архивах Монголии.

После монастырской жизни Д. Лувсаншарав год прослужил в армии, что связано с решением МНРП о допуске представителей ламства к службе в армии [Кузьмин 2016: 258]. Ламы действительно проходили военную службу — в основном лекарями, называли их «тибетскими лекарями», хотя все они были монголами: факт изучения тибетской медицины послужил образованию такого их именования [Монголия в документах 2019: 157]. Был ли Лувсаншарав эмчи, или другой специальности, неизвестно. В армии, по данным за 1928 г. ${ }^{6}$, лекарей было около 20, все они получали жалованье (18 840 тугриков в год), каждый лекарь «имел лошадь, на которую получал фураж... на тибетские медикаменты ассигновывалось по смете Военведа [военное ведомство. - K. О.] 19 и более тысяч тугриков» [Монголия в документах 2019: 159].

\section{Партийная деятельность}

В 1925 г. Д. Лувсаншарав вступил в партию. Так началась его партийная карьера. Надо отметить, что привлечение аратов и буддийских священнослужителей к революционной работе исходило из реалий жизни. В письме Б. 3. Шумяцкого Э.-Д. Ринчино (октябрь 1921 г.) даются прямые указания по революционной работе в Монголии и подготовке кадров из числа простых монголов: «Нужны в массах партийные очаги ... Это задача, не терпящая ни секунды отлагательства. Пусть простолюдины и будут корявыми чиновниками и офищерами [здесь и далее курсив мой. - K. O.], но зато они дадут устойчивость новой власти, зато через них придет к этой власти до сих пор еще инертная монгольская масса. Я бы ... всюду выискивал бы мало-мальски пригодных к административной, хозяйственной и военной работе людей» [Монголия в документах Коминтерна 2012a: 68]. Это высказывание в полной мере можно отнести и к буддийским священнослужителям, т. е. ставка была сделана на молодых, «с талантом и способностями самородков, ... кровно связанных с делом новой власти» [Монголия в документах Коминтерна 2012а: 68], а сословная принадлежность на первых порах не имела принципиального значения. Что касается социального состава членов партии, то, по сведениям представителей МНРП Ц. Гурсэда и С. А. Нацова (в изложенном на подготовленном к V конгрессу

${ }^{6}$ Сведения за более ранние годы не выявлены. 


\section{История}

Коминтерна докладе 7 от 21 июня 1924 г.), среди партийцев было «аратов (простолюдинов) - 1214 чел., тайджей и нойонов (высшее сословие) - 90 чел., лам — 131 чел., ... грамотных — 554 чел., неграмотных — 881 чел.» [Монголия в документах Коминтерна 2012a: 104].

Восхождение Д. Лувсаншарава на партийный олимп началось после VIII съезда партии (февраль 1930 г.), когда его избрали заместителем секретаря и заведующим орготделом ЦК партии. В апреле того же года состоялась его обстоятельная беседа с представителем Исполнительного комитета Коммунистического интернационала (далее - ИККИ) С. Е. Чуцкаевым, которая проходила в форме диалога (вопросы С. Е. Чуцкаева и ответы Д. Лувсаншарава). Актуальность беседы не вызывает сомнений, особенно после восстания в Чандмань-ульском (ныне - Увс) аймаке (1925 г.), когда уже зрели волнения в Хубсугульском, Архангайском аймаках и других регионах Монголии. Предваряя беседу, C. Е. Чуцкаев изложил свое видение положения в Монголии: основной враг страны и партии - «феодал», который все еще имеет большое влияние на аратов, и при первой же возможности способен возглавить и организовать восстание против существующей власти; «лама также враг страны», но не столь опасен и не активен. Но сможет сыграть большую роль как «консолидирующая сила», что подтверждается событиями в Чандмань-ульском аймаке [Монголия в документах 2019: 275]. А далее разговор в форме вопросов и ответов шел о джасской кампании, средствах существования лам, восстании, отношении низшего ламства к обогащению высших лам и населения страны - к конфискации имущества высших лам и др. Если суммировать содержание беседы, то С. Е. Чуцкаев детально прояснял возможность предотвращения будущих восстаний в других регионах страны, а также пути реализации антирелигиозной пропаганды [Монголия в документах 2019: 275-283]. Менее чем через месяц С. Е. Чуцкаев по результатам беседы в письменной форме (в так называемой «Записке») изложил свое видение ламского вопроса с критикой суждений Лувсаншарава [Монголия в документах 2019: 270-275]. Их диалог не случаен: в мае 1924 г. скончался Богдо-гэгэн VIII, высшие ламы сразу приступили к поиску его перерождения и даже отправляли в Лхасу делегацию8. В 1926 г. в Монголии был принят закон об отделении церкви от государства, что означало начало наступления на буддийскую церковь и ослабление ее позиций. Согласно решению V Великого народного хурала МНР (1928-1929) поиски нового Богдо были прекращены [Батсайхан 2018: 361].

Гонения на религию и буддийское духовенство были продолжены. 7 января 1929 г. состоялось совещание в Восточном секретариате ИККИ по монгольскому вопросу, на котором обсуждались разные проблемы, в частности, о предпринимаемых партийным руководством мерах по разложению и ослаблению буддийского духовенства среди широких слоев населения. Однако в выступлениях участников совещания звучала и иная точка зрения; так, один из участников совещания, некто Терешников, видел в буддизме монолитность

\footnotetext{
7 Доклад на Конгрессе не был заслушан [Монголия в документах Коминтерна 2012a: 99].

${ }^{8}$ В 1926 г. в Тибет была отправлена советско-монгольская миссия. Помимо других задач миссии монголы (сотрудники МИД МНР) имели особые поручения своего правительства — провести религиозные обряды по случаю кончины Богдо-гэгэна VIII и получить официальное благословение Далай-ламы XIII о его следующей реинкарнации.
} 
партии и объявлял его «не чем иным, как идеологией партии» ${ }^{9}$ [Монголия в документах Коминтерна 2012a: 410]. На этом же заседании уполномоченный Коминтерна М. И. Амагаев прояснил ситуацию с привлечением бывших лам в партию: если вначале партия пошла на альянс с ламством «в лице его верхушечной влиятельной части, включая Богдо-гэгэна» в связи с борьбой против Китая и «остатков русской контрреволюции», то сейчас актуальна их «политическая нейтрализация» и даже «перетягивание на свою сторону», особенно после кончины Богдо-гэгэна VIII [Монголия в документах Коминтерна 2012а: 402]. Выступление уполномоченного Коминтерна можно считать генеральной линией монгольской партии, оно во многом объясняло решение части лам снять с себя монашеские обеты, перейти в светское состояние, а особо деятельным и претендующим заявиться на государственной или административной работе включиться в активную политическую жизнь, что, вероятно и произошло в случае с Д. Лувсаншаравом.

В июне 1932 г. на III пленуме ЦК МНРП избранный в секретариат ЦК Д. Лувсаншарав выступил с докладом, который в 1937 г. опубликовали в журнале «Современная Монголия» [Лубсан-Шарап 1937а]. В тексте статьи была проанализирована слабая работа парторганизаций. В частности, Д. Лувсаншарав озвучил нелицеприятные для партийцев сведения. Судя по судебным постановлениям за 1936-1937 гг., из общего числа осужденных [численность осужденных не приводится. - $K$. O.] за нарушения законов наказаны 339 членов партии. К числу других недоработок партии он отнес: нерегулярный созыв партсобраний и посещаемость собраний (только 70 \%). В качестве рекомендаций и «чрезвычайно важного» Д. Лувсаншарав предложил аймачным руководителям активнее выдвигать «на хозяйственные, кооперативные, государственные работы лучших людей» с двухгодичным их обучением, «усилить политическую зоркость, революционную бдительность, проявлять инициативу». На заключительном заседании пленума он призывал к беспощадному подавлению врагов народа [читай: ламства. $-K . O$. .], то есть объявил, что «надо взбудораживать массу», что приведет к успеху в работе [Лубсан-Шарап 1937б: 108-110, 123].

На IX съезде МНРП (28 сентября - 5 октября 1934 г.) Д. Лувсаншарав выступил с докладом о задачах партии в развитии национальной культуры. Примечательна его речь: обозначив (по данным за 1934 г.) численность обучающихся в монастырских школах (18 тыс. детей) и государственных школах (5 тыс.), он заключает: «реакционного высшего ламу» необходимо заменить «школьным учителем», потому что «учитель может повседневно наблюдать арата, приспосабливаясь к его индивидуальным особенностям», и, соответственно, араты по вопросам политики должны обращаться «не к багшам, а к работникам партии и госактива» (цит. по: [Кузьмин 2016: 315]). Данный тезис четко увязывается с партийными установками: необходимо «напоминать аратству, что ... монастыри никогда не пытались распространить грамоту среди окрестного населения... В то время как раньше монастырь являлся единственным путем

\footnotetext{
${ }^{9}$ В циркулярном письме (1930 г.) ЦК МНРП и ЦК Революционного союза молодежи (РСМ) прямо говорилось: «идеология буддизма во всех своих оттенках является идеологией, безусловно враждебной нашей партии» [Монголия в документах Коминтерна 2012б: 29].
} 


\section{История}

для получения некоторой культуры ${ }^{10}$, теперь таким путем является ... светская школа... светское просвещение является в их глазах опасным конкурентом». В связи с этими установками партии предлагалось убеждать родителей забирать своих детей из монастырей, им обеспечивалось «поступление в школы наравне с детьми аратской бедноты» [Монголия в документах Коминтерна 2012б: $32,33]$. В докладе были также озвучены вопросы «преодоления феодальных пережитков - территориальной замкнутости и разобщенности, слепой веры в святость феодальных авторитетов, неравноправия женщин, ... европейской медицины (серьезным бедствием оставались социальные болезни), новой идеологии и культуры, и проблема подготовки национальных кадров» [Рощин 1999: 275]. И в этих тезисах доклада Д. Лувсаншарава явственно просматриваются предписания партии в отношении женщин: «разъяснять им, что пребывание в монастыре более $1 / 4$ всего мужского населения страны не только разрушает монгольскую семью, но и возлагает на женщину особое бремя ... воспитание ребенка и забота о нем. Когда же ребенок подрастает, если это мальчик, его чаще всего отрывают от матери и берут в монастырь ... светских мужчин слишком мало, для того чтобы каждая женщина могла создать свою семью и вести нормальную здоровую жизнь» [Монголия в документах Коминтерна 2012б: 32, 33]. Указания партии относительно европейской медицины были таковы: «преимущество научной европейской медицины над тибетским знахарством необходимо делать исходным для разъяснения аратству ... ламство эксплуатирует темноту и отсталость населения и даже болезни использует в качестве источников своего дохода» [Монголия в документах Коминтерна 2012б: 32]. Судя по цитатам из доклада Д. Лувсаншарава, просматривается однозначный отказ от монастырского прошлого к новой партийной жизни. На этом съезде он был избран секретарем ЦК партии. По итогам работы делегации ИККИ на съезде состоялось заседание президиума (ноябрь 1934 г.), на котором выступил Ш. З. Элиава, озвучивший стратегию (вероятно, согласовав с советским руководством) борьбы с духовенством на основе конкретных данных: в стране на 250000 мужчин всех возрастов приходится примерно 115000 лам... на 200 тыс. юрт - 115 тыс. лам, на семь человек - один лама, а на одного члена партии - 13 лам, на 1000 человек - один партиец. Исходя из этих данных, продолжил Ш. З. Элиава, получается, что «на культурном фронте пока еще безраздельно господствует монастырь», поэтому «происходит соревнование правительственного аппарата, государственной организации с этой мощной организацией, связанной с населением гораздо крепче и глубже, чем правительство» [Монголия в документах Коминтерна 2012б: 401]. Именно поэтому «сосуществование этих двух систем — революционного государства и ламаистской церкви, как это было раньше, невозможно», но и ликвидация

\footnotetext{
${ }^{10}$ В 1938 г. Д. Лувсаншарав в своей статье «Ламский вопрос в МНР» еще дальше развил свои мысли: «Вся духовная и философская литература в абсолютном большинстве держалась на тибетском языке, учеба в монастырях велась на тибетском языке ... мы хотим иметь свой национальный язык, свою грамоту, свою национальную литературу, свою национальную по форме и революционную по содержанию культуру. Ламство внедряло в аратские массы тибетскую реакционную культуру (хотя хочу сказать, что в тибетской культуре есть рациональное, разумное ядро), тем самым оскорбляло национальные чувства, национальные революционные традиции наших арат, тем самым ламство вело к вырождению монгол ... это есть прямая измена народу, измена национальным интересам» [Лубсан-Шарап 1938: 104].
} 
церкви уже не так злободневна: «лобовые удары кончились безуспешно. Были проекты в 1932 г. заточить 13000 высших лам в концлагерь, и думали этим разрешить проблемы религиозных верований Монголии и упразднить влияние церкви. Обожглись на этом деле. Теперь наступил период, когда надо очень организованную осаду повести против монастыря» [Монголия в документах Коминтерна 2012б: 403].

В ноябре того же 1937 г. выходит постановление Совета министров МНР, согласно которому вводилось «обучение национальной грамоте детей, не достигших совершеннолетия и проживающих в монастырях», добровольность лам в учебе с 18 лет. Кроме того, предлагалось вести разъяснительную работу среди успешно обучающегося низшего ламства, заинтересовывая их льготами и помощью со стороны административных, общественных и культурных, просветительных и других органов. В этом же постановлении говорилось об организации кустарно-промысловых артелей, в которых уже задействовано несколько тысяч лам [Лубсан-Шарап 1938: 114].

Партийные высоты Д. Лувсаншаравом были достигнуты. Однако он стал в большей степени известен тем, что, согласно решению 44-го пленума ЦК партии (13 марта 1937 г.), возглавил ламскую комиссию при ЦК, куда также вошли Х. Чойбалсан (заместитель премьер-министра, министр внутренних дел), Г. Дэмид (военный министр, главком) и С. Довчин (министр финансов). Не последнюю роль в назначении главой комиссии сыграло его 20-летнее пребывание в монастыре и, по его собственному и мнению его соратников, характеристика его как специалиста по ламскому вопросу. На пленуме партии в 1937 г. с докладом о работе среди лам за 1936 г. выступил Х. Чойбалсан, в очередной раз продекларировавший, что «монастыри и ламы - пережиток феодализма и главное препятствие развития монгольской революции», доход монастырей МНР составлял «как минимум 34 млн тугриков», что являлось тяжкой ношей населения, поэтому «их (ламство) надо ликвидировать» [Кузьмин 2016: 322]. Ламская комиссия развернула свою деятельность широко: судебные процессы, аресты сотен тысяч лам, простых аратов, вчерашних руководителей партии и правительства (подробнее см.: [Рощин 2005: 78-81; Кузьмин 2016: 331-334, 344, 345]). Главная ее цель состояла «в беспощадном уничтожении реакционного ламства: ...уничтожали, уничтожаем и будем уничтожать» (!) [Лубсан-Шарап 1938: 115].

В 1938 г. в журнале «Современная Монголия» был опубликован перевод с монгольского языка статьи Д. Лувсаншарава «Ламский вопрос в МНР», в котором изложены программные тезисы работы партии и правительства, мало отличающиеся от прежних выступлений. Начинается статья с изложения причины появления буддизма в Монголии, которую он видит в «экономической отсталости, раздробленности и некультурности своей страны ....ламство веками строило свое реакционное миропонимание на основе буддийского учения, буддийской религии, буддийской философии» [Лубсан-Шарап 1938: 90, 92]. По его мнению, «политический смысл ламской реакционной философии» заключается в «сохранении господства богатых классов, эксплуатации и порабощении народных масс». Однако, отвергая «чуждые реакционные ламские идеи, „непротивление злу“, идеи покорности и смирения», автор статьи предлагает 


\section{История}

«сплотить вокруг партии трудящиеся аратские массы... развить национальную по форме и революционную по содержанию культуру... распространить идеи марксизма-ленинизма, вести беспощадную борьбу с реакционным ламством, с его реакционными идеями», ибо «ламство есть изменник, продающий свою родину японским империалистам, оно является агентурой японского империализма в нашей стране» [знал бы автор статьи, что не пройдет и года, как его обвинят по этим же пунктам. - $K$. O.], его задача «поднять в стране контрреволюционное восстание и уничтожить народно-революционный строй, тем самым уничтожить национальную независимость в МНР; разрушить дружественные отношения между МНР и Советским Союзом, изолировать МНР, ослабить ее и тем самым облегчить внешним врагам захват нашей страны; открыть границы нашей страны врагам японского империализма и передать в колониальное рабство». В статье приводятся данные по численности различных слоев населения: «дворян - 5,6 \%, лам - 44,5 \%, арат, крепостных и бессословных - 49,8 \%, т. е. в количественном отношении - 100000 лам $^{11}$, проживающих в более чем 600 монастырях», на содержание которых ежегодно тратится 51600000 тугриков без налогов и подношений на религиозные обряды [Лубсан-Шарап 1938: 93, 94, 97, 101]. «Замечательный» вывод делает автор статьи: «Если бы эти огромные средства были использованы для хозяйства и культуры, то страна была бы неузнаваемой... одной из передовых стран ...ннаша партия должна беспощадно бороться с ними как с „паразитами“» [Лубсан-Шарап 1938: 94]. Кроме того, ламство, по его мнению, подрывает «оборонную мощь страны: здоровая молодежь уходит в монастыри и не выполняет обязанности по защите страны» [Лубсан-Шарап 1938: 95]. Особого внимания заслуживает раздел статьи, в котором автор для разгрома реакционной силы в стране предлагает следующие основные направления: «подрыв экономических основ феодально-ламского класса, в этом направлении приняты ряд мер и законов (обложение ламства подоходным налогом, военным налогом, конфискация монастырского хозяйства) и др.; ...политический разгром высшего реакционного ламства». Монастыри превратились «в контрреволюционные центры, ....мы много вскрыли и уничтожили, ...еще немало имеется подпольных контрреволюционных организаций, со временем они будут вскрыты и уничтожены» [Лубсан-Шарап 1938: 106, 110, 111].

Жизнь Д. Лувсаншарава, как и многих партийных и государственных деятелей Монголии, трагически завершилась в 1941 г. За несколько месяцев до ареста, а именно 7 марта 1939 г., на заседании президиума ЦК МНРП с сообщением о «непартийных действиях А. Амара ${ }^{12}$ выступил Д. Лувсаншарав, а в начале июля 1939 г. после IV пленума ЦК МНРП член президиума ЦК, секретарь ЦК МНРП Д. Лувсаншарав, «ранее разоблачавший происки контрреволюционеров

\footnotetext{
${ }_{11}$ Для сравнения: по данным уполномоченного Коминтерна М. И. Амагаева, за 1926 г. из 600 тыс. населения - 200 тыс. лам или 30 \%; по информации из Российского государственного архива социально-политической истории, 91601 лам (или 13,39 \%); в сведениях из Архива внешней политики Российской Федерации за тот же год данные не сильно разнятся: 91650 лам (13,4 \%) [Кузьмин 2016: 298]. Согласно стенограмме совещания в Восточном секретариате ИККИ по монгольскому вопросу (7 января 1929 г.), «население [Монголии. - K. О.] только восемьсот тысяч человек» [Монголия в документах Коминтерна 2012a: 421].

${ }^{12}$ А. Амар - премьер-министр (1936-1939 гг.), арестован в 1939 г., расстрелян в 1941 г., реабилитирован в 1962 г.
} 
и... клеймивший А. Амара за антипартийные действия», по иронии судьбы был арестован и отправлен в Советский Союз [Рощин 1999: 294, 295 ].

\section{Отзывы о Д. Лувсаншараве}

На всех партийных заседаниях и съездах доклады Д. Лувсаншарава были идеологически выдержаны, да и отзывы о нем не сильно различаются. Так, в письме (от 18 июля 1930 г.) представителя Коминтерна при ЦК МНРП В. Н. Кучумова заместителю заведующего Восточным секретариатом ИККИ, секретарю Дальбюро ИККИ П. А. Мифу даны характеристики высшему партийному эшелону, в том числе секретарю ЦК Д. Лувсаншараву: «Бывший бедняк-лама. ... Срывается на личных отношениях, несдержан. Далеко не тверд и прямолинеен ... несмотря на эти особенности личного характера, в своей политической линии не отличается от ... предыдущих цекистов» [Монголия в документах Коминтерна 20126: 56]. В докладе инструктора агитационно-пропагандистского отдела ЦК МНРП С. А. Нацова «Итоги первой конференции ${ }^{13}$ Монгольской народно-революционной партии» отмечены следующие особенности характера Д. Лувсаншарава: «...он вообще какой-то непонятный человек, и я имею факты, которые характеризуют его недостаточно хорошо. Когда ЦК хотел назначить его председателем Колхозцентра, он всячески сопротивлялся и сильно при этом волновался. Я считаю это неправильным, ибо когда посылают товарища на передовой участок, нельзя от этого отказываться, и делаю вывод, что едва ли Лупсан-Ширап [Лувсаншарав. - K. O.] будет бороться вместе с нами на трудном фронте борьбы за социализм ${ }^{14} \gg$ [Монголия в документах Коминтерна 2012б: 116]. Монголовед, доктор исторических наук С. К. Рощин на основе богатого фактического материала из российских архивов и монгольских источников также оценивает его как «честолюбивого, не отличающегося твердостью и выдержкой, недостаточно деловитого, но неплохого организатора, специалиста по ламскому вопросу. ... не был самостоятелен в своих действиях, обычно шел за главным лидером [Рощин 2008: 93, 95]. Как тут не вспомнить его беседу с заместителем наркома внутренних дел России М. П. Фриновским в Москве в ноябре 1937 г. относительно судьбы бывшего премьер-министра П. Гэндэна: где проводить над ним суд ${ }^{15}$ — в Москве или Улан-Баторе. Ответ Д. Лувсаншарава поражает некоторой холодностью и даже равнодушием - перевозить Гэндэна в Монголию необязательно, «нежелательно» [Рощин 1999: 290].

Следует отметить, что и в Москве его считали «человеком „второго“ плана, помощником» [Рощин 2008: 93, 95]. Тем не менее человек «второго» плана Д. Лувсаншарав вошел в состав особой полномочной комиссии (так называемой «тройки»), наряду с Х. Чойбалсаном (председателем) и Г. Цэрэндоржем (министром юстиции), на совести которых многие тысячи арестованных, замученных

\footnotetext{
13 Первая партийная конференция МНРП проходила в г. Улан-Баторе с 26 декабря 1930 г. по 13 января 1931 г.

${ }^{14}$ Как впоследствии оказалось, С. А. Нацов ошибся, характеризуя Д. Лувсаншарава; в 1931 г. он только взбирался на политический верх и оказался очень даже активным борцом «на трудном фронте».

15 П. Гэндэн - премьер-министр Монголии (1934-1936 гг.), обвинен в шпионаже в пользу Японии, создании в стране сети террористических организаций и контрреволюционной деятельности, арестован сотрудниками НКВД в Форосе (Крым, СССР) в июле 1937 г., расстрелян 20 ноября 1937 г., реабилитирован в 1962 г.
} 


\section{История}

и расстрелянных [Рощин 2005: 78-79]. Вырисовывается, с одной стороны, «непонятный», «недостаточно деловитый», не способный принять на себя ответственность партиец, с другой - жесткий и непримиримый, расчетливый карьерист. Надо принять во внимание, что он в течение 20 лет находился в одном из значимых монастырей Монголии. Как могла произойти такая метаморфоза с человеком? Хотя есть мнение, что «особой жестокостью отличались те, кто стал партийцами из послушников» [Кузьмин 2016: 345]. Ответ, видимо, кроется в его характере, нереализованности на поприще религии, возможно, сыграла роль неудовлетворенность занимаемым местом в структуре Мурэнского монастыря. Вполне вероятно, что толчком к уходу из монастыря послужили какие-то психологические моменты. Нельзя исключать и резкую смену идеологии, соответственно, и мировоззрения (когда во главу угла часть людей ставила личную выгоду и карьеризм) в этот непростой, даже жесткий период в истории страны. «Противоречивость и двойственность времени» явно сказалась в переломе мировоззрения, в полной мере «поколение молодых революционеров на себе ощутило разрыв между здравым смыслом и теми идеологическими установками, которые пришли на смену старым» [Хомушку 1998: 85-86]. В подтверждение своих слов тувинская исследовательница, доктор философских наук О. М. Хомушку приводит высказывание ученого из Австрии о тувинских студентах, обучавшихся в КУТВе: «Сотни юных восточников - якуты, монгольл, тувинцы, узбеки, корейцы, афганцы, персы воспитываются там в продолжение трех лет для того, чтобы у себя на родине взорвать все старое. В три года шаманисты становятся атеистами, поклонники Будды - поклонниками трактора. Эти славные ребята со скудным знанием русского языка, начиненные боевыми словами и лозунгами, настроенные столь же фанатично, как это требовалось от миссионеров, получают задачу продвинуть своих соотечественников в XXI столетие» (цит. по: [Хомушку 1998: 85]).

\section{Заключение}

В XX в. сложилось характерное для Монголии явление, когда бывшие ламы становились на путь борьбы с религией и период пребывания в монастыре не имел значения для последующей их карьеры; исключением стал Д. Бодоо. Следует отметить, что не только Д. Лувсаншарав, бывший лама, пошел в политику. Так, Д. Бодоо (1885-1922 гг.), выходец из семьи арата-бедняка, в детстве был отдан в монастырь, стал ламой, владел тибетским, китайским, русским и маньчжурским языками. Его считали «неформальным лидером по влиянию, авторитету и человеческим качествам»; с марта 1921 г. он являлся министром иностранных дел, с апреля - премьер-министром Временного правительства. Х. Чойбалсана (1895-1952 гг.) в 12-летнем возрасте отдали в монастырь, но через четыре года пребывания он сбежал в Ургу, где и началась его бурная политическая жизнь. А. Данзан (Япон-Данзан, 1895-1932 гг.), из бывших лам, в 1921 г. вступил в партию, с 1922 г. был избран в ЦК партии, в 1924-1925 гг. являлся полпредом Монголии в Советском Союзе, далее был на хозяйственной работе, в 1929-1932 гг. работал в Ученом комитете, умер во время следствия по политическому делу. Л. Лааган (1887-1940 гг.) — также бывший лама, в 1928 г. на VII съезде партии избран председателем ЦКК МНРП, на VI Великом народном хурале (1930 г.) - председателем президиума Малого хурала. Все 
упомянутые партийные и государственные деятели, кроме Х. Чойбалсана, были репрессированы.

Молодой республике не хватало кадров, а получившие образование в монастырях ламы были грамотными и просвещенными людьми, со знанием нескольких языков, что было неоспоримым их преимуществом, при этом некоторые молодые люди продолжали получать образование либо у себя на родине, либо в советских вузах. Конечно, нельзя говорить о массовом уходе лам в политику, однако пример Д. Лувсаншарава - яркая иллюстрация взаимоотношений власти и религии. И эта проблема, надеюсь, будет предметом будущих исследований.

\section{Литература}

Батсайхан 2018 - Батсайхан О. Последний великий хан Монголии Богдо Джебцзундамба-хутухта VIII. Жизнь и легенды. М.: Товарищество научных изданий КМК, 2018. 406 c.

Коминтерн ба Монгол 1996 - Коминтерн ба Монгол: баримтын эмхэтгэл / [эрдэм шинжилгээний удирдагч, Ч. Дашдаваа, В. П. Козлов; техник редактор Э. Хүрэлбаатар] (= Коминтерн и Монголия: сб. док. / [науч. рук. Ч. Дашдаваа, В. Козлов; техредактор Э. Хурэлбаатар]). Улаанбаатар: Монгол Улсын Архивын Хэрэг Эрхлэх Газар, 1996. $502 \mathrm{x}$.

Кузьмин 2016 - Кузьмин С. Л. Теократическая государственность и буддийская церковь Монголии в начале XX в. М.: Товарищество научных изданий КМК, 2016. 496 с.

Лубсан-Шарап 1937а - Лубсан-Шарап. Методы борьбы с политической беспечностью, двурушничеством и об активизации партийно-политической работы // Современная Монголия. 1937. № 6 (25). С. 99-114.

Лубсан-Шарап $1937 б$ - Лубсан-Шарап. Заключительное слово // Современная Монголия. 1937. № 6 (25). С.121-123.

Лубсан-Шарап 1938 - Лубсан-Шарап. Ламский вопрос в МНР // Современная Монголия. 1938. № 4-6 (29-31). С. 90-114.

Монголия в документах 2019 - Монголия в документах из архивов ФСБ России (19221936 гг.). / науч. ред. В. В. Наумкин, отв. ред. К. В. Орлова, В. В. Грайворонский. М.: ИВ РАН, 2019. $528 \mathrm{c}$.

Монголия в документах Коминтерна 2012а - Монголия в документах Коминтерна (1919-1934). Ч. I (1919-1929) / науч. ред. Б. В. Базаров. Улан-Удэ: Изд-во БНЦ СО РАН, 2012. $527 \mathrm{c}$.

Монголия в документах Коминтерна 20126 - Монголия в документах Коминтерна (1919-1934). Ч. II (1930-1934) / науч. ред. Б. В. Базаров. Улан-Удэ: Изд-во БНЦ СО РАН, 2012. $491 \mathrm{c}$.

Монголын сүм хийдийн түүхэн 2009 - Монголын сүм хийдийн түүхэн товчоон (= Краткая история монгольских монастырей) / ерөнхий ред. С. Цэдэндамба. Улаанбаатар: Admon, 2009. 888 х.

Монголын хүрээ хийд 2018 - Монголын хүрээ хийд, лам нар (XVI-XX зууны эхэн) (= Монгольские монастыри и ламы (XVI - начало XX вв.)) / зохиогч Н. Хатанбаатар, хянан тохиолдуулсан 3. Лонжид. Улаанбаатар: ШУАХ, ТҮүх археологийн хүрээлэн, $2018.343 \mathrm{x}$.

Позднеев 1993 - Позднеев A. М. Очерки быта буддийских монастырей в связи с отношениями сего последнего к народу. Изд. репринтное. Элиста: Калм. кн. изд-во, $1993.512 \mathrm{c}$.

Рощин 1999 - Рощин С. К. Политическая история Монголии (1921-1940 гг.). М.: ИВ PAH, 1999. 327 c. 


\section{История}

Рощин 2005 - Рощчин С. К. Маршал Монголии Х. Чойбалсан. Штрихи биографии. М.: ИВ РАН, 2005. $160 \mathrm{c.}$

Рощин 2008 - Рощиин С. К. П. Гэндэн - монгольский национальный лидер. Штрихи биографии. М.: ИВ РАН, 2008. $160 \mathrm{c.}$

Сүхбаатар $1997-$ Сүхбаатар О. Монгол хэлний харь үгийн толь (=Словарь иностранных слов монгольского языка). Улаанбаатар: Admon, 1997. 233 х.

Хомушку 1998 - Хомушку О. М. Религия в истории культуры тувинцев. М.: Наука, 1998. $177 \mathrm{c}$.

\section{References}

Batsaikhan O. $8^{\text {th }}$ Jebtsundamba Khutukhtu: The Last Great Khan of Mongolia. Life and Legends. Moscow: KMK Science Publ., 2018. 406 p. (In Russ.)

Bazarov B. V. (ed.) Mongolia in Documents of the Comintern: 1919-1934. Vol. I: 1919-1929. Ulan-Ude: Buryat Scientific Center (Sib. Branch) of RAS, 2012. 527 p. (In Russ.)

Bazarov B. V. (ed.) Mongolia in Documents of the Comintern: 1919-1934. Vol. II: 1930-1934. Ulan-Ude: Buryat Scientific Center (Sib. Branch) of RAS, 2012. 491 p. (In Russ.)

Dashdavaa Ch., Kozlov V. P. (eds.) The Comintern and Mongolia: Collected Documents. Khurelbaatar E. (layout). Ulaanbaatar: Mongolian Archives, 1996. 502 p. (In Mong.)

Khatanbaatar N. Mongolian Monasteries and Lamas: $16^{\text {th }}$ to Early $20^{\text {th }}$ Centuries. Lonzhid Z. (ed.). Ulaanbaatar: Mongolian Academy of Sciences, Institute of History and Archaeology, 2018. 343 p. (In Mong.)

Khomushku O. M. Religion in Tuvan Cultural History. Moscow: Nauka, 1998. 177 p. (In Russ.)

Kuzmin S. L. Mongolia in the Early $20^{\text {th }}$ Century: Theocratic State and Buddhist Church. Moscow: KMK, 2016. 496 p. (In Russ.)

Lubsan-Sharap. Concluding words. Sovremennaya Mongoliya. 1937. No. 6 (25). Pp. 121-123. (In Russ.)

Lubsan-Sharap. Methods of struggle against political negligence and dualism. Revisiting the activation of party and political work. Sovremennaya Mongoliya. 1937. No. 6 (25). Pp. 99-114. (In Russ.)

Lubsan-Sharap. The Lama question in Mongolian People's Republic. Sovremennaya Mongoliya. 1938. No. 4-6 (29-31). Pp. 90-114. (In Russ.)

Naumkin V. V., Orlova K. V., Graivoronsky V. V. (eds.) Federal Security Service Archives: Mongolia Documented, 1922-1936. Moscow: Institute of Oriental Studies (RAS), 2019. 528 p. (In Russ.)

Pozdneev A. M. Essays on the Life of Buddhist Monasteries and Buddhist Clergy in Mongolia, and Relations of the Latter to the People. Reprint. Elista: Kalmyk Book Publ., 1993. 512 p. (In Russ.)

Roshchin S. K. Kh. Choybalsan, the Marshal of Mongolia: Biographical Glimpses. Moscow: Institute of Oriental Studies (RAS), 2005. 160 p. (In Russ.)

Roshchin S. K. P. Genden - a National Leader of Mongolia: Biographical Glimpses. Moscow: Institute of Oriental Studies (RAS), 2008. 160 p. (In Russ.)

Roshchin S. K. Political History of Mongolia: 1921-1940. Moscow: Institute of Oriental Studies (RAS), 1999. 327 p. (In Russ.)

Sükhbaatar O. A Dictionary of Foreign Words in the Mongolian Language. Ulaanbaatar: Admon, 1997. 233 p. (In Mong.)

Tsedendamba S. (ed.) A Brief History of Mongolian Temples and Monasteries. Ulaanbaatar: Admon, 2009. 888 p. (In Mong.) 